Syntax Literate: Jurnal Ilmiah Indonesia p-ISSN: 2541-0849 e-ISSN: 2548-1398

Vol. 6, No. 5, Mei 2021

\title{
ANALISIS PENGEMBANGAN PRODUK INOVASI TERHADAP COMPETITIVE ADVANTAGE
}

\section{Reza Eko Muchtadin}

Mahasiswa Magister Manajemen, Universitas Kristen Maranatha Bandung Jawa Barat, Indonesia

Email: rezaeko@ rocketmail.com

\section{Abstract}

This research was conducted to analyze the development of innovation products Fish skin Cek Aat in Palembang city against competitive advantage. The method used is a descriptive qualitative approach, to obtain information and an in-depth picture of the development of fish skin products. Researchers collected data using in-depth interview methods to fish skin owners and managers of Cek Aat as well as consumers. The interview was conducted at the location of Fish Skin Cek Aat in between working hours, so that the author can see directly the process of innovation product development. In addition, interviews are also conducted at recess, so that respondents better understand and focus on answering the author's questions. From this research obtained the conclusion that the development of innovation products to competitive advantage fish skin products Cek Aat can develop well, because the products made by Cek Aat is very popular with the people of Palembang. Savory taste and affordable price, make people love it. In addition, there is still a rare similar product in Palembang city, making Cek Aat has few competitors, so that Cek Aat can redevelop its business in accordance with the objectives set by the company at the beginning of its establishment.

Keywords: competitive advantage; innovation products

\section{Abstrak}

Penelitian ini dilakukan untuk menganalisis pengembangan produk inovasi fish skin Cek Aat di Kota Palembang terhadap competitive advantage. Metode yang digunakan adalah pendekatan kualitatif deskriptif, untuk memperoleh informasi dan gambaran secara mendalam tentang pengembangan produk fish skin. Peneliti mengumpulkan data dengan menggunakan metode wawancara mendalam (in-depth interview) kepada pemilik dan manager fish skin Cek Aat serta konsumen. Wawancara dilakukan di lokasi fish skin Cek Aat di sela-sela jam kerja, agar penulis dapat melihat langsung proses pengembangan produk inovasi. Selain itu, wawancara juga dilakukan pada waktu istirahat, supaya para responden lebih memahami dan lebih fokus menjawab pertanyaan penulis. Dari penelitian ini diperoleh kesimpulan bahwa pengembangan produk inovasi terhadap competitive advantage produk fish skin Cek Aat dapat berkembang dengan baik, karena produk yang dibuat oleh Cek Aat sangat digemari oleh masyarakat kota Palembang. Rasa yang gurih dan harga yang terjangkau, membuat masyarakat menggemarinya. Selain itu, masih jarangnya produk serupa di Kota Palembang, membuat Cek Aat 
mempunyai sedikit pesaing, sehingga Cek Aat dapat mengembangkan lagi usahanya sesuai dengan tujuan yang sudah ditetapkan perusahaan pada awal pendiriannya.

Kata Kunci: competitive advantage; produk inovasi

\section{Pendahuluan}

Perusahaan mempunyai tujuan untuk dapat tetap berjalan dan berkembang, tujuan yang bisa dicapai melalui usaha mempertahankan dan meningkatkan tingkat penjualan/laba perusahaan. Hal ini dapat dilakukan apabila perusahaan dapat mempertahankan dan meningkatkan produk, melalui usaha mencari dan mengembangkan produk yang tepat. Pengembangan produk baru atau inovasi produk sangat penting bagi sebuah perusahaan. Karena teknologi yang semakin maju, peningkatan kompetisi global, dan kebutuhan pasar yang semakin dinamis, perusahaan harus mampu berinovasi untuk memenuhi kebutuhan pasar (Cooper \& Kleinschmidt, 1990).

Inovasi produk merupakan hasil dari pengembangan produk baru oleh suatu perusahaan atau industri, baik yang sudah ada maupun dari produk sebelumnya. Dari produk lama yang sudah mencapai titik jenuh di pasaran, diperlukan sebuah inovasi untuk mengganti produk lama tersebut. Penggantian ini dapat berupa produk pengganti yang secara total baru atau dengan perkembangan produk lama yang lebih modern dan up to date, sehingga dapat terus memenuhi keinginan konsumen (Amerk, 2013).

Apabila kebutuhan konsumen telah terpenuhi, diharapkan timbul kepuasan pada konsumen tersebut, sehingga pada masa yang akan datang mereka akan datang kembali membeli produk yang dibuat berikutnya terhadap produk yang sama. Produsen dapat meningkatkan hasil produksinya dengan melakukan pengembangan produk untuk hasil yang lebih baik.

Pengembangan produk erat kaitannya dengan keberhasilan perusahaan dalam menjalankan dan meningkatkan penjualan perusahaan, karena dengan terus mengembangkan produk diharapkan konsumen baru akan bertambah. Tentu hal ini diharapkan akan meningkatkan penjualan perusahaan, dan apabila produk yang dibuat sesuai dengan harapan dan keinginan konsumen.

Proses pengembangan produk, perusahaan juga harus mampu untuk menentukan segmen pasar yang akan dituju, sehingga tingkat keberhasilan diterima produk yang dikembangkan akan semakin besar. Karena itu perlu diperhatikan juga perilaku konsumen. Menurut (Hasan, 2013), perilaku konsumen adalah suatu proses yang terlibat ketika individu atau kelompok memilih, menggunakan, membeli atau mengatur produk, ide, jasa dan juga pengalaman untuk memuaskan keinginan dan kebutuhan konsumen. Dalam pengertian pengembangan produk inovasi, makna produk dan inovasi perlu diketahui agar gambaran penuh kaitan keduanya dapat dipahami. Produk adalah sesuatu yang ditawarkan sebagai usaha untuk mencapai tujuan yang ditetapkan oleh perusahaan perusahaan, untuk memenuhi kebutuhan dan keinginan konsumen. Menurut (Kotler \& 
Armstrong, 2010), "Produk ialah sesuatu yang dapat ditawarkan atau dijual ke pasar untuk memenuhi keinginan atau kebutuhan", sedangkan (Saladin, 2007) menjelaskan: "Produk adalah segala sesuatu yang dapat ditawarkan atau dijual ke pasar untuk diperhatikan, dibeli, dipergunakan, atau dikonsumsi, dan yang dapat memuaskan keinginan dan kebutuhan."

Pempek CEK AAT adalah home industry pangan pempek yang beralamat di Jalan Keramasan No. 77 Kertapati, Kota Palembang, Sumatera Selatan, CEK AAT berdiri mulai tahun 11 Februari 2002, awalnya CEK AAT hanya memproduksi pempek, kerupuk, dan kemplang khas Palembang yang menjadi oleh-oleh wisatawan yang berkunjung ke Kota Palembang. Persaingan keras dengan toko yang menjual produk serupa, semakin banyak toko pempek dan kerupuk di Kota Palembang, dan lokasi CEK AAT yang dekat dengan toko pesaing membuat CEK AAT memikirkan cara agar dapat bersaing dengan menginovasi produknya yang sudah ada. Owner CEK AAT, Ibu Alinda Topo, sering melihat kulit ikan yang dibuang sebagai sampah dan tidak dapat dimanfaatkan lagi. Lalu muncul gagasan untuk mengolah kulit ikan yang tersisa menjadi produk yang dapat dijual. Ibu Alinda Topo menguji coba produk itu selama tiga tahun, akhirnya berhasil mengolah kulit ikan atau fish skin yang seringkali dibuang menjadi kerupuk kulit ikan atau fish skin. Produk fish skin CEK AAT dicoba untuk dijual di pasaran pada bulan Februari 2019.

Fish skin adalah makanan yang terbuat dari bahan dasar kulit ikan yang diolah menjadi makanan kering yang renyah. Fish skin sendiri terbuat dari bahan dasar ikan belida dan ikan gabus mengingat banyaknya ikan tersebut di Kota Palembang. Selain itu persaingan dalam produk fish skin tidak terlalu banyak dibandingkan dengan krupuk atau pempek-pempek yang sudah menjadi ciri khas Palembang. Penggunaan bahan dasar ikan gabus dan belida sendiri dipilih karena mempunyai banyak manfaat diantaranya manfaat dari ikan gabus itu sendiri adalah pembentukan dan pertumbuhan otot, mempercepat penyembuhan luka, menjaga keseimbangan cairan dalam tubuh, memperbaiki gizi buruk, sehat untuk pencernaan, sedangkan manfaat ikan belida sendiri adalah mengandung kalsium, mengandung vitamin A, omega 3, mencegah penyakit jantung koroner, mengurangi kolestrol, dan sebagai antioksidan (Kusumaningrum \& Asikin, 2016).

(Johnson, 2012) memberi definisi keunggulan kompetitif sebagai cara perusahaan atau organisasi menciptakan nilai bagi penggunanya yang baik lebih besar dari biaya untuk menciptakannya serta superior dari kompetitor. (Porter, 2011) berpendapat bahwa nilai adalah apa yang dapat membuat pembeli mau untuk membayar, dan nilai yang superior bersumber dari penawaran harga yang ditawarkan lebih murah dari kompetitor untuk manfaat yang sama atau memberikan manfaat unik yang lebih sepadan untuk harga yang lebih tinggi. (Porter, 2011) mengatakan bahwa ada tiga tipe dasar keunggulan kompetitif yang dapat digabungkan dengan lingkup kegiatan, seperti, fokus, kepemimpinan biaya, dan diferensiasi. Fokus sendiri dibagi lagi menjadi fokus biaya dan fokus diferensiasi. 
Keunggulan biaya berupa kemampuan perusahaan untuk mempunyai biaya yang lebih murah di bidang tersebut. Dengan keunggulan biaya, perusahaan unggul dalam operasi yang efektif dan efisien. Pempek fish skin CEK AAT menawarkan harga yang murah dan terjangkau bagi produknya karena struktur harga yang rendah tetapi efisien. Diferensiasi ialah keunggulan yang dapat digunakan untuk menawarkan manfaat dari produk yang dibuat, keunikan produk yang dibuat atau lebih superior dibandingkan dengan kompetitor. Perusahaan dengan keunggulan seperti ini bisa mengenakan harga yang lebih tinggi dari pesaingnya, dan memperoleh margin laba atau keuntungan yang lebih tinggi dari pesaingnya. Umumnya, keunggulan jenis ini dapat diperoleh dengan berbagai cara seperti kualitas, inovasi, atau pelayanan. Untuk segi harga, pempek fish skin CEK AAT jauh lebih murah, tetapi memiliki karakteristik yang unik seperti tekstur pempek yang lebih renyah. Terakhir, fokus adalah kemampuan untuk memahami dan membaca suatu segmen pasar atau konsumen secara mendalam dan membentuk strategi terbaik untuk melayani segmen pasar dan konsumen tersebut. Segmen pasar pempek fish skin CEK AAT lebih kepada mahasiswa dan anak muda. Fokus biaya yang lebih rendah dari kompetitor dan fokus diferensiasi dari rasa gurih dan tekstur yang renyah menjadikan keunggulan kompetitif dari pempek fish skin CEK AAT.

\section{Metode Penelitian}

Pendekatan yang digunakan dalam penelitian ini adalah pendekatan kualitatif deskriptif, yaitu untuk memperoleh informasi serta gambaran secara mendalam tentang pengembangan produk fish skin. (Moleong, 2013), mengatakan bahwa penelitian deskriptif mengumpulkan data berupa kata-kata, gambar dan tidak menggunakan angka.

(Sugiyono, 2012) mengemukakan bahwa metode penelitian kualitatif adalah metode yang bisa pakai untuk meneliti pada kondisi obyek yang alamiah, dimana peneliti adalah sebagai instrumen utama, teknik pengumpulan data yang dilakukan yaitu dengan cara triangulasi atau gabungan, analisis data bersifat induktif, dan hasil penelitian kualitatif lebih menekankan makna dari pada generalisasi.

Alasan penelitian ini menggunakan pendekatan kualitatif karena data yang didapatkan dari penelitian bersifat deskriptif yang dapat diperoleh melalui kata-kata, dokumen dan tulisan yang berasal dari sumber yang dapat dipercaya. Data tersebut dapat dibuat berupa teks wawancara, videotape, dokumen pribadi, catatan lapangan, memo dan dokumen resmi lainnya, (Moleong, 2013).

\section{A. Jenis Data}

Data-data yang dikumpulkan pada penelitian ini adalah untuk memperoleh informasi yang kuat dengan pokok bahasan di atas dengan menggunakan data primer. Menurut (Sugiyono, 2012), data primer adalah data yang bisa langsung memberikan data kepada pengumpul data. Data primer yang dipakai dalam penelitian ini diperoleh dengan melakukan wawancara dengan narasumber yang telah dipilih.

\section{B. Teknik Penentuan Data}


Untuk mendapatkan data yang ingin diperoleh untuk suatu penelitian dalam hal ini menggunakan teknik pengumpulan data. Dalam penelitian ini peneliti memilih jenis penelitian kualitatif maka data yang diperoleh harus jelas, spesifik dan mendalam, untuk itu data akan dikumpulkan dengan menggunakan metode wawancara. Wawancara adalah percakapan yang dilakukan oleh kedua pihak untuk mendapatkan hasil atau maksud tertentu, yaitu pewawancara sebagai orang yang mengajukan pertanyaan kepada narasumber sebagai orang yang memberikan jawaban atas pertanyaan, (Moleong, 2013). Wawancara dilakukan dengan pemilik usaha fish skin, data-data yang dikumpulkan berupa laporan pelaksanaan pengembangan fish skin, sehingga akan diketahui bagaimana kualitas bahan baku, kelezatan rasa dan dampak dari pengembangan produk tersebut.

(Sugiyono, 2012) mengatakan bahwa pengumpulan data bisa diperoleh dari hasil wawancara, dokumentasi, observasi, dan gabungan atau triangulasi. Teknik wawancara yang dilakukan adalah dengan wawancara yang semi terstruktur. Jenis wawancara ini termasuk ke dalam kategori in-depth interview yang dalam pelaksanaannya lebih bebas bila dibandingkan dengan wawancara terstruktur, (Sugiyono, 2012).

\section{Teknik Pengumpulan Data}

\section{Cetak Biru (Blue Print) Penelitian}

Pengembangan produk adalah suatu strategi yang dilakukan perusahaan untuk pertumbuhan atau pengembangan perusahaan dengan cara menawarkan produk baru atau produk yang telah dimodifikasi ke segmen pasar yang sekarang (Kotler \& Keller, 2016). Pelaksanaan pengembangan produk akan mendorong perusahaan untuk mampu menggunakan sumber daya yang dimiliki secara efektif dan perlunya jawaban yang lebih akurat yang meliputi 5W1H. (Griffin, Ricky, W., \& Ebert, 2013), mengemukakan tujuh aspek dalam pengembangan produk terdiri dari pencarian gagasan, penyaringan gagasan, pengembangan dan pengujian konsep, analisis bisnis, pengembangan prototipe, pengujian produk dan uji pemasaran, komersialisasi.

\section{Hasil dan Pembahasan}

\section{A. Hasil Penelitian}

\section{Gambaran Umum Perusahaan}

Bedasarkan data yang disadur langsung dari wawancara, Fish Skin Cek Aat merupakan usaha makanan kulit ikan.Mulai beroperasi dari tanggal 11 februari di Kota Palembang. Usaha Fish Skin Cek Aat .

\section{Komponen Inovasi Produk}

\section{a) Pencarian gagasan}

Inovasi dan eksperimen suatu perusahaan pasti mengalami hambatan dan kesulitan, karena inovasi produk itu sangat penting bagi perusahaan tak bisa dibantah, bahwa terdapat hubungan yang kuat antara inovasi produk dengan pengembangan pasar, artinya adalah, semakin inovatif dan kreatif 
perusahaan membuat produk seperti keinginan konsumen, semakin cepat pula pasar berkembang. Maka, lemahnya inovasi produk yang di buat oleh perusahaan bagaimanapun juga akan berimbas secara signifikan kepada tumbuhnya pengembangan pasar.

Menurut (Griffin, Ricky, W., \& Ebert, 2013), mengatakan bahwa pengembangan produk dimulai dengan pencarian gagasan bagi produkproduk baru. Para manajer puncak harus bisa mendefinisikan atau menjelaskan produk dan pasar yang ingin ditekankannya menyatakan tujuan dari dibuatnya produk baru tersebut. Merek harus menyatakan berapa banyak usaha yang harus dicurahkan. Hasil wawancara bahwa gagasan usaha fish skin karena pasar makanan di Palembang yang banyak menggunakan bahan baku ikan, sehingga kulit ikan pun menjadi gagasan baru untuk dikembangkan.

Dapat disimpulkan bahwa pasar makanan bahan baku ikan di Palembang banyak diproduksi hingga menjadi gagasan baru dengan kulit ikan.

\section{B. Pembahasan}

Pengembangan produk inovasi terhadap competitive advantage dilakukan dengan 7 indikator atau dimensi sebagai berikut:

\section{Pencarian Gagasan}

Gagasan usaha adalah suatu ide yang bertujuan untuk dapat mewujudkan suatu pemikiran-pemikiran yang baru dan diterapkan dengan suatu tindakan. Dalam mencari suatu gagasan usaha berarti berusaha untuk bisa menemukan ide-ide yang nantinya ide-ide tersebut dapat menjadi langkah awal dalam menentukan bisnis apa yang ingin dikembangkan dan ingin dibangun. Ide bisnis seperti ini tidak dapat muncul secara tiba-tiba. Alasan sang pemilik usaha karena di Kota Palembang banyak memanfaatkan ikan belida dan ikan gabus sebagai bahan dasar mpek mpek atau kerupuk kemplang, tetapi kulitnya dibuang sehingga memiliki ide untuk memanfaatkan kulit ikan dengan mengolah menjadi bahan yang layak dikonsumsi.

\section{Penyaringan Gagasan}

Pada penelitian ini Cek Aat pernah melakukan mengolah berbagai kulit ikan tetapi dari beberapa ikan hanya ikan gabus saja yang dapat diolah dan enak dikonsumsi. Beberapa cara untuk dapat melakukan pembentukan atau pemilihan ide produk dan yang terpenting adanya dukungan seperti tersedianya tenaga kerja lokal, tersedianya bahan baku, tersedianya pasar lokal, teknologi, mendapat prioritas dari pemerintah, peluang di masa yang akan datang dan sebagainya. Dukungan tersebut telah tersedia bag usaha Cek Aat sehingga membuat fish skin dinilai layak untuk dijadikan usaha.

\section{Pengembangan dan Pengujian Konsep}

Ide atau gagasan yang telah lulus penyaringan kemudian selanjutnya dapat dikembangkan menjadi beberapa alternatif konsep produk. Konsep produk 
berbeda dengan gagasan produk dan citra produk. Gagasan produk adalah gagasan bagi kemungkinan produk yang dapat dianggap oleh perusahaan bisa ditawarkan ke pasar. Konsep produk adalah versi terinci dari ide yang diungkapkan dalam istilah konsumen yang punya arti. Pengembangan sudah dilakukan dengan melibatkan cukup banyak pihak terutama dari konsumen atau orang-orang terdekat kita jadi sebelum meluncurkan produk baru dengan memberikan tester kepada pelanggan apabila layak maka diproduksi dan dipasarkan tetapi berdasarkan rekomendasi dari konsumen, apakah perlu perbaikan atau sudah cukup atau ada inovasi yang lain

\section{Analisis Bisnis}

Cek Aat menganalisa bisnis dengan melihat perkembangan dari produk tersebut biasanya dari tingkat penjualan produk tersebut apakah mengalami penurunan atau mengalami peningkatan pada setiap periode tertentu. Ide produk yang sudah ada perlu dianalisis lebih mendalam lagi sehingga bisa diketahui dengan cepat apa yang menjadi kekuatan dan kelemahannya dengan memperhatikan situasi lingkungannya. Cek Aat harus bisa mempertimbangkan situasi dan pelaku atau lingkungan yang sesuai dengan bisnisnya. Oleh karena itu ide produk fish skin sudah diperhitungkan dan kemukinan situasi atau lingkungan yang mempengaruhi bisnis tersebut.

\section{Pengembangan Prototipe}

Pengembangan konsep adalah pengembangan tahapan lebih lanjut dari ide yang sudah terpilih dari konsep produk untuk kemudian dapat di proses ke tahap selanjutnya. Itulah mengapa dalam hal pengembangan tahapan produk atau ide harus mempunyai atau memiliki alternatif lain, yang dapat disesuaikan dengan keinginan dan kebutuhan konsumen atau pasar yang paling menarik.

Tingkat ketertarikan pasar sasaran atas produk fish skin, yang kemudian dikembangkan dengan tujuan mendapatkan produk dengan daya tarik pasar yang paling tinggi. Apabila produk fish skin banyak diminati maka dilakukan pengembangan produk walaupun produk ini mudah ditiru tetapi kualitas produk dan rasa yang berbeda dibanding dengan yang lainnya.

\section{Pengujian Produk dan Uji Pemasaran}

Pengujian produk dan pemasaran mulai dari seperti pola pengemasan yang sudah cukup baik dibandingkan dengan produk-produk. Strategi awal pemasaran yang dikembangkan pada awal peluncuran produk kepasar, sehingga bisa diterima pasaran dan memulai untuk menunjukkan pertumbuhannya. Berdasarkan hasil observasi pada pasar sasaran, Cek Aat telah menetapkan proposisi nilai yang direncanakan, pangsa pasar, sasaran laba, dan penjualan untuk tahun-tahun pertama dengan jelas. Akan tetapi perusahaan belum menetapkan garis besar dari model distribusi serta anggaran pemasaran untuk tahun pertama. Hasil pemasaran pada fish skin Cek Aat mengenai rasa dapat diolah sesuai dengan variasi rasa yang tren saat ini. Pemasaran yang dilakukan sudah ke wilayah Palembang dan lingkungan kampus. 
Reza Eko Muchtadin

\section{Komersialisasi}

Keberadaan fish skin akan menjadi menarik karena peluang pengembangan makanan ringan sangat terbuka luas karena dapat dukungan dari faktor internal yang kuat seperti besarnya jumlah penduduk khususnya di Palembang yang menjadi pasar produk industri makanan, tingkat pendapatan masyarakat yang semakin meningkat yang mendorong permintaan akan produk makanan olahan, Sebagian besar bahan baku produksi cukup tersedia di Palembang, cukup tersedianya tenaga kerja dengan upah yang relatif rendah. Hasil produk fish skin cek aat layak untuk diproduksi, dikemas dan dijual.

\section{Kesimpulan}

Hasil penelitian ini menunjukkan bahwa pengembangan produk inovasi terhadap competitive advantage produk fish skin yang dilakukan Cek Aat dapat berkembang dengan baik, karena produk yang di buat oleh Cek Aat sangat digemari oleh masyarakat khususnya dikota Palembang, karena rasanya yang gurih dan harganya yang terjangkau membuat masyarakat menggemarinya, selain itu juga masih jarangnya produk fish skin di kota Palembang, membuat Cek Aat memiliki sedikit pesaing sehingga Cek Aat dapat mengembangkan lagi usahanya sesuai dengan tujuan yang telah di tetapkan oleh perusahaan, dan sejauh ini sudah mencapai target yang di buat oleh perusahan Cek Aat itu sendiri, dan diharapkan produk dari Cek Aat itu makin disukai. 


\section{BIBLIOGRAFI}

Amerk, I. (2013). Manajemen Inovasi. Yogyakarta: CV. Andi Offset.

Cooper, Robert G., \& Kleinschmidt, Elko J. (1990). New product success factors: a comparison of 'kills' versus successes and failures. R\&D Management, 20(1), 4763. Google Scholar

Griffin, Ricky, W., \& Ebert, R. J. (2013). Bisnis Jilid 1. Jakarta: Erlangga.

Hasan, A. (2013). Marketing. Yogyakarta: Media Pressindo.

Johnson, G. W. (2012). Exploring Strategy: Text and Cases (Eleventh E). Harlow: Pearson Education Limited.

Kotler, Philip, \& Armstrong, Garry. (2010). Prinsip-Prinsip Pemasaran, Jilid 1 dan 2 Edisi Kedua Belas. Jakarta: Erlangga. Google Scholar

Kotler, Philip, \& Keller, Kevin Lane. (2016). Marketing Management 15th Edition. England. Pearson Education, Inc. Google Scholar

Kusumaningrum, I., \& Asikin, N. A. (2016). Pemanfaatan tulang ikan belida untuk fortifikasi kalsium pada olahan kerupuk. Lembaga Penelitian Dan Pengabdian Masyarakat, Universitas Mulawarman. Google Scholar

Moleong, Lexy J. (2013). Metode Penelitian Kualitatif, Bandung: Remaja Rosdakarya. Mosal. Google Scholar

Porter, Michael E. (2011). Competitive advantage of nations: creating and sustaining superior performance. simon and schuster. Google Scholar

Saladin, Djaslim. (2007). Industri Pemasaran dan Unsur-Unsur Pemasaran. Bandung: CV Linda Karya. Google Scholar

Sugiyono, P. D. (2012). Metode Penelitian Kuantitatif Kualitatif Dan R\&D (Vol. 8). Alfabeta. Bandung. Google Scholar

\section{Copyright holder:}

Reza Eko Muchtadin (2021)

First publication right:

Journal Syntax Literate

This article is licensed under: 